\title{
Two Uncommon Sites of Metastasis: Breast and Hypophysis Metastases of Head and Neck Adenoid Cystic Carcinoma Detected by FDG PET/CT
}

\author{
Baş Boyun Adenoid Kistik Karsinomlu Olguda Iki Olağan Dışı Metastaz Alanı: Hipofiz ve Meme
}

\author{
Evrim Sürer Budakl, Şenay Yıldırım², Sevim Yıldız³, Ali Ozan Öner4 ${ }^{4}$ Şeyda Gündüz 5 \\ IAntalya Training and Research Hospital, Clinic of Nuclear Medicine, Antalya, Turkey \\ 2Antalya Training and Research Hospital, Clinic of Pathology, Antalya, Turkey \\ ${ }^{3}$ Antalya Training and Research Hospital, Clinic of Radiology, Antalya, Turkey \\ 4Afyon Kocatepe University Faculty of Medicine, Clinic of Nuclear Medicine, Afyon, Turkey \\ ${ }^{5}$ Antalya Training and Research Hospital, Clinic of Medical Oncology, Antalya, Turkey
}

\begin{abstract}
Adenoid cystic carcinoma (ACC) is a rare epithelial malignancy arising from secretory glands, particularly the salivary glands. It tends to invade nerves and has a high potential for distant hematogenous metastasis, especially to the lungs, bone, liver and brain. The breast and hypophysis are not common sites of ACC metastatic disease. Herein, we report a case of ACC of the head and neck region with two unusual sites of metastases, the hypophysis and breast.

Keywords: PET/CT, adenoid cystic carcinoma, breast, hypophysis, metastasis
\end{abstract}

Öz

Adenoid kistik karsinom (AKK), sekretuar glandlardan özellikle de tükrük bezlerinden köken alan nadir bir epitelyal tümördür. Sinir invazyonu sıktır ve özellikle akciğer, kemik, karaciğer ve beyin gibi organlara uzak hematojen metastaz yapma potansiyeli yüksektir. Ancak, meme ve hipofiz AKK için tipik metastaz alanları değildir. Bu çalışmada, hipofiz ve meme gibi iki olağan dışı alana metastazı olan baş-boyun AKK olgusunu sunmaktayız.

Anahtar kelimeler: PET/BT, adenoid kistik karsinom, meme, hipofiz, metastaz

Address for Correspondence: Evrim Sürer Budak MD, Antalya Training and Research Hospital, Clinic of Nuclear Medicine, Antalya, Turkey Phone: +90 2422494400 E-mail: evrimsurer@hotmail.com ORCID ID: orcid.org/0000-0002-8318-0785

Received: 23.03.2017 Accepted: 10.07.2017

${ }^{\circ}$ Copyright 2017 by Turkish Society of Nuclear Medicine

Molecular Imaging and Radionuclide Therapy published by Galenos Yayınevi. 

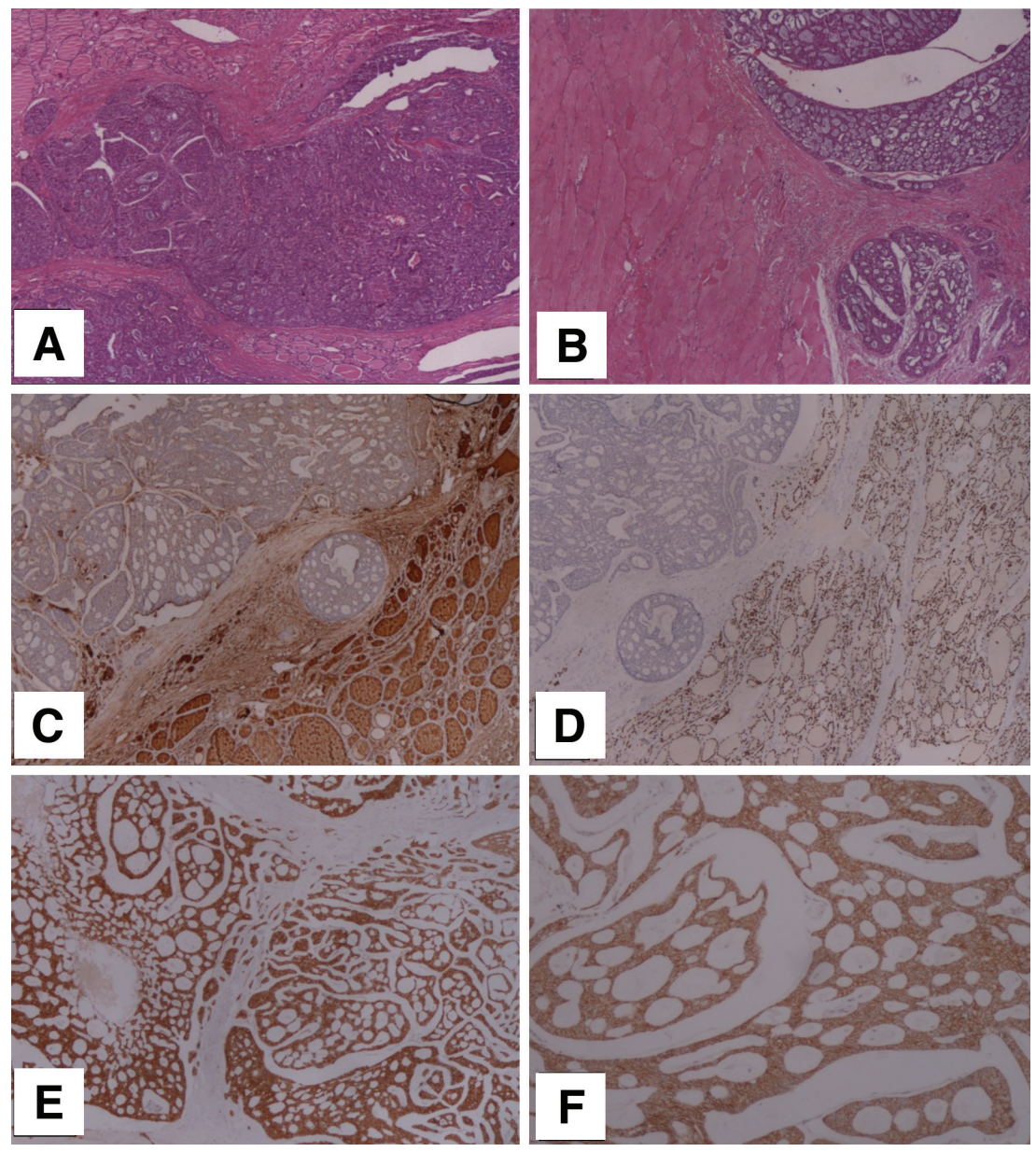

Figure 1. A 49-year-old woman presented with a left cervical mass. The ultrasound examination revealed a gross mass adjacent to the thyroid gland and she underwent total excision of the mass along with total thyroidectomy. Histopathologic examination of the $9.5 \times 10 \mathrm{~cm}$ mass revealed adenoid cystic carcinoma (ACC) infiltrating both the thyroid and adjacent smooth muscle tissue. (A, B): Hematoxylin and eosin (H\&E) staining of the primary tumor: Tumor cells were arranged in cord-like or acinar-like by atypical hyperplastic epithelial cells forming a cribriform and tubular pattern with a mucoid luminal material (x40). (C, D): Tumor cells were negative for thyroglobulin (C) and TTF-1 (D) excluding thyroid origin (x40). Tumor cells were immune-positive for CD-117 (E) indicating ductal origin and E-cadherin (F) (x100). She was accepted as ACC of the head and neck region. The patient was referred to FDG PET/CT scanning for initial staging. PET/CT images revealed multiple hypermetabolic lung metastasis and a mild FDG uptake in the operation region secondary to surgery. She received radiotherapy and chemotherapy, and was stable for about 20 months follow-up
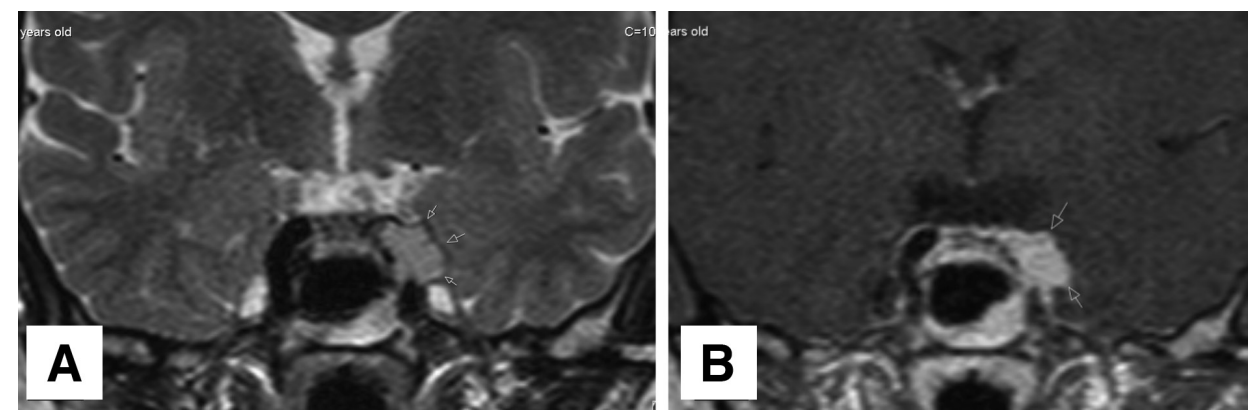

Figure 2. (A, B) Twenty months after the initial diagnosis, the patient developed sudden vision loss. The cranial magnetic resonance imaging T2 and post-contrast T1 weighted coronal images revealed a mildly T2 hyper-intense and homogenously enhancing left parasellar mass compatible with metastasis. The patient received radiotherapy. Pituitary metastasis is very rare, accounting for only about $1 \%$ of pituitary surgeries (1). In the literature, although extraordinary metastasis sites of ACC were reported including the kidney (2) and vertebrae (3), there are only two cases reporting hypophysis metastasis $(4,5)$ 

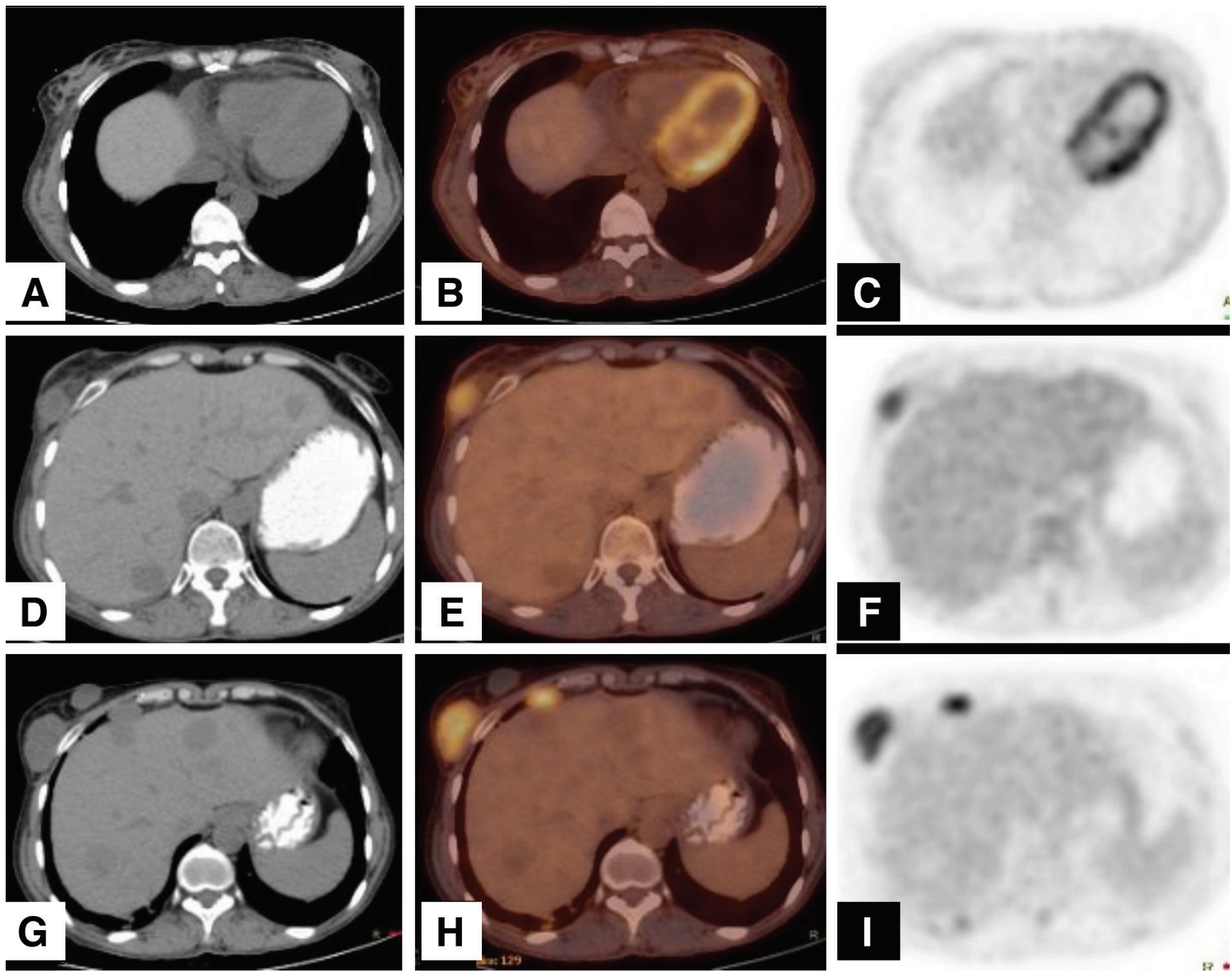

Figure 3. The PET/CT images performed for response evaluation at the $24^{\text {th }}$ month after initial diagnosis showed two new lesions in the right breast. The interval between the last two PET/CT imaging was about one year, and these breast lesions were new findings. (A, B, C): The initial FDG PET/ $C T$ images with no lesion both anatomically and metabolically in the breast tissue. (D, E, F): The second year FDG PET/CT examination revealed an unexpected, lobulated hypermetabolic solid mass measuring $19 \times 30 \mathrm{~mm}$ with a SUV $\max$ of 5.2 in the lower outer quadrant of the right breast. There was also a smaller non-metabolic lesion next to this lesion. The patient underwent incisional biopsy, the histopathologic examination revealed ACC in the lateral lesion while the other one was composed of necrotic material. The histology and immunophenotyping of the breast ACC is similar to that of the salivary gland. Therefore, it is difficult to differentiate metastatic disease from a primary breast ACC by pathologic examination. The diagnosis is usually based on clinical behavior of the tumor. In our case, based on the clinical findings (sudden onset in one year), it was diagnosed as metastasis from the primary tumor. Hypermetabolic right parasternal, anterior diaphragmatic/paracardiac lymph nodes were also detected in the same examination. $(G, H, I)$ : In the following FDG PET/CT, her metastatic breast lesion progressed anatomically (24x35 mm) while remaining metabolically stable (SUV max $:$ 5.6). Anterior mediastinal, paracardiac, parasternal and right anterior mediastinal lymph nodes were also detected as new findings while the existing lung metastasis were progressing. (D, G): The patient also had multiple hypodense stable lesions in the liver that did not show any FDG uptake, compatible with hemangiomas. The patient's chemoradiotherapy is still on-going in the third year of diagnosis. In the consecutive follow-up PET/CT images performed at 4 month intervals, her metastatic lung lesions, lymph nodes and breast lesion all have been progressing both in dimension and metabolically.

Breast metastasis from extra-mammary neoplasms is very rare, with a reported incidence of $0.5-3 \%$ (6). Also, the incidence of unexpected breast focal uptake in 18 F-DG-PET/CT is reported as $0.36-1.12 \%(7,8,9)$. The rate of malignancy in incidental FDG-avid breast foci was reported in a range of $37.5-83 \%(10,11,12)$. Under these circumstances, it can be concluded that focal FDG-avid breast lesions need further evaluation, especially in cases with known malignancies 

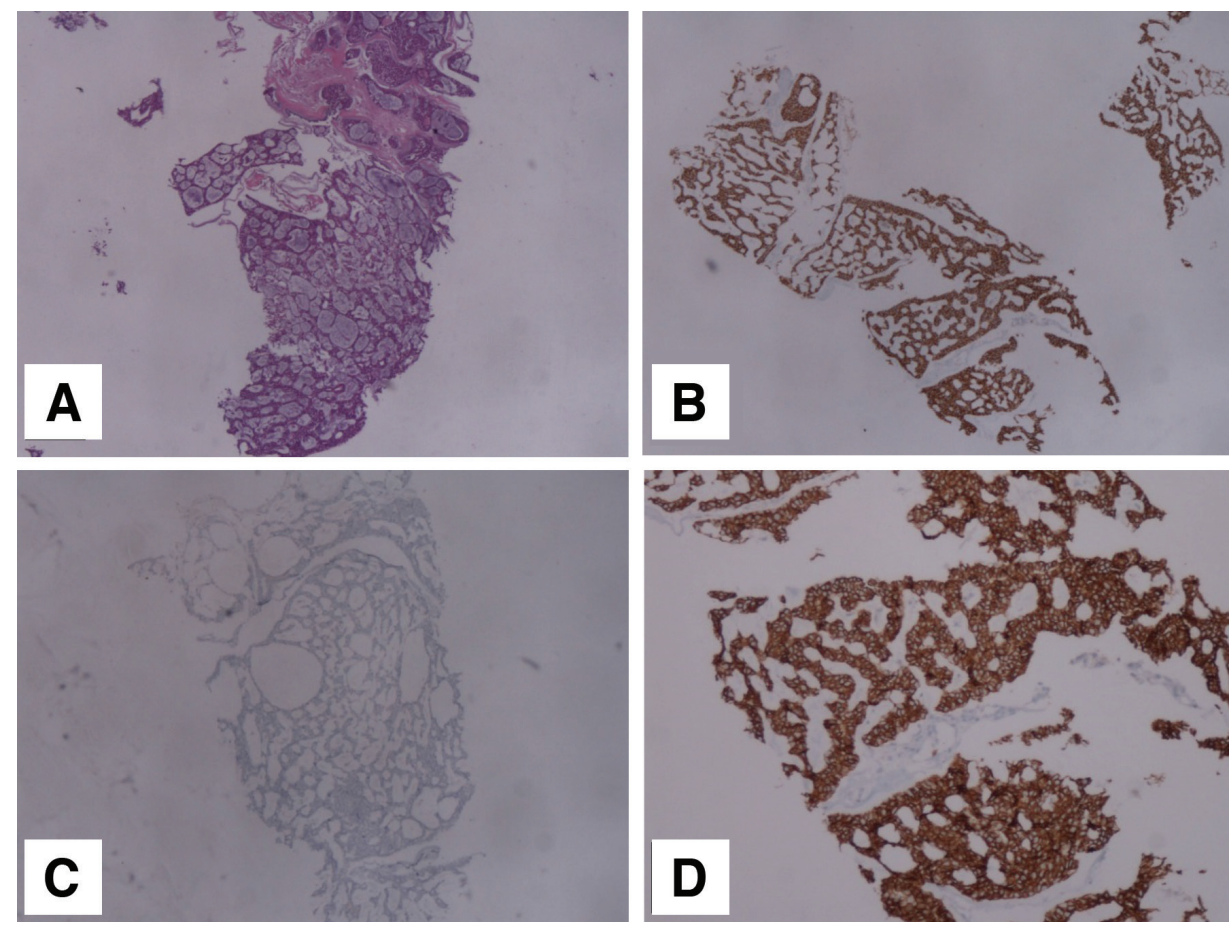

Figure 4. Histopathologic examination of the breast lesion revealed ACC. (A): Invasive tumor cells forming cylindromatous nodules and glandular spaces with basophilic secretion (x40) (B): CD-117 positivity in tumor cells (x40) (C): Tumor cells were negative for Estrogen receptor (x40) (D): Tumor cells were immune-positive for E-cadherin (x100)

\section{Ethics}

Informed Consent: Consent form was filled out by all participants.

Peer-review: Internally peer-reviewed.

\section{Authorship Contributions}

Surgical and Medical Practices: E.S.B., S..Y., S.Y., Ş. G., Concept: E.S.B., Design: E.S.B., Data Collection or Processing: E.S.B., Ş.Y., S.Y., Ş.G., Analysis or Interpretation: E.S.B., A.O.Ö., Literature Search: E.S.B., A.O.Ö., Writing: E.S.B.

Conflict of Interest: No conflict of interest was declared by the authors.

Financial Disclosure: The authors declared that this study received no financial support.

\section{References}

1. Fassett DR, Couldwell WT. Metastases to the pituitary gland. Neurosurg Focus 2004;16:E8.

2. Qiu DS, Xu LY, Hu XY. Imaging appearance of a singular metastatic adenoid cystic carcinoma of the right kidney: A case report and literature review. Oncol Lett 2014;8:2669-2671.

3. Feng H, Wang J, Guo P, Xu J, Feng J. C3 Vertebral Metastases From Tongue Adenoid Cystic Carcinoma: A Rare Case Report. Medicine (Baltimore) 2015;94:e1135.

4. Kawamata T, Harashima S, Kubo O, Hori T. Intrasellar remote metastasis from adenoid cystic carcinoma of parotid gland: case report. Endocr J 2006;53:659-663.
5. Hughes DJ, Retzlaff A, Sims J, O'Brien E, Giannini C, Huston J, Van Gompel JJ. Adenoid Cystic Carcinoma Metastatic to the Pituitary: A Case Report and Discussion of Potential Diagnostic Value of Magnetic Resonance Elastography in Pituitary Tumors. World Neurosurg 2016;91:669.e11-14.

6. Lee SK, Kim WW, Kim SH, Kim S, Choi JH, Cho EY, Han SY, Hahn BK, Choe JH, Kim JH, Kim JS, Lee JE, Nam SJ, Yang JH. Characteristics of metastasis in the breast from extramammary malignancies. J Surg Oncol 2010;101:137-140.

7. Litmanovich D, Gourevich K, Israel O, Gallimidi Z. Unexpected foci of (18)F-FDG uptake in the breast detected by PET/CT: incidence and clinical significance. Eur J Nucl Med Mol Imaging 2009;36:15581564.

8. Kang BJ, Lee JH, Yoo leR, Kim SH, Choi JJ, Jeong SH, Yim HW. Clinical significance of incidental finding of focal activity in the breast at 18F-FDG PET/CT. AJR Am J Roentgenol 2011;197:341347.

9. Dunne RM, O'Mahony D, Wilson G, McDermott R, O'Keeffe SA. The role of the breast radiologist in evaluation of breast incidentalomas detected on 18-fludeoxyglucose positron emission tomography/CT. Br J Radiol. 2013;86:2013003.

10. Litmanovich D, Gourevich K, Israel O, Gallimidi Z. Unexpected foci of (18)F-FDG uptake in the breast detected by PET/CT: incidence and clinical significance. Eur J Nucl Med Mol Imaging 2009;36:15581564.

11. Korn RL, Yost AM, May CC, Kovalsky ER, Orth KM, Layton TA, Drumm D. Unexpected focal hypermetabolic activity in the breast: significance in patients undergoing 18F-FDG PET/CT. AJR Am J Roentgenol 2006;187:81-85

12. Kang BJ, Lee JH, Yoo IR, Kim SH, Choi JJ, Jeong SH, Yim HW. Clinical significance of incidental finding of focal activity in the breast at 18F-FDG PET/CT. AJR Am J Roentgenol 2011;197:341-347. 